\title{
The Influence of Investment Decisions, Funding Decisions, Risk of Strategy, To Efficeincy, Finance Performance, Value of Firm, Good Corporate Governance As Moderating Variable In The Mining Company Coal Sub Sector Go Public In Indonesia Stock Exchange
}

\author{
Nuuridha Matiin \\ University doctoral student, \\ August 17, 1945, Surabaya, Indonesia \\ Tri Ratnawati \\ University lecturer, \\ August 17, 1945, Surabaya, Indonesia \\ Slamet Riyadi \\ University lecturer, \\ August 17, 1945, Surabaya, Indonesia
}

\begin{abstract}
The problems of the mining company is the financial performance of various issuers in the mine sector is not encouraging I-quarter 2012. Average-performance emitters of mining records profit below expectations. The decline in profit that, triggered by the production down and did not reach its target production. Some companies are old as TINS and ANTM. Conditions were worsened by the weather that keeps rain and drought if erratic. The purpose of this study is to determine The Influence of Investment Decisions, Funding Decisions, Risk of Strategy, To Efficeincy, Finance Performance, Value of Firm, Good Corporate Governance (GCG) as The Moderate Variable In The Mining Company Coal Sub Sector Go Public In Indonesia Stock Exchange. The population used in this study is the whole mining company coal sector sub go public in Indonesia stock exchange (idx), which obtained the data from the Indonesian Capital Market Directory (ICMD). Sample from a population of 18 companies. This research uses of data analysis in SEM (Structure Equational Modeling) using the Partial Least Square 2.0. The results obtained show that Investment decisions don't effect significantly to efficiency, Investment decisions effect significantly to financial performance, Investment decision effect significantly to value of firm, Funding decisions effect significantly to efficiency, Funding decisions effect significantly to financial performance, Funding decisions effect significantly to value of firm, Risk of strategy effect significantly to efficiency, Risk of strategy effect significantly to financial performance, Risk of strategy don't effect significantly to value of firm, Efficient effect significantly to financial performance, Efficient effect significantly to the value of firm, GCG as moderating variable effect significantly to value of firm, GCG as moderating variable effect significantly to financial performance and Financial performance effect significantly to value of firm.
\end{abstract}

Keywords: investment decisions, funding decisions, risk of strategy, efficiency, good corporate governance, financial performance, value of firm.

\section{INTRODUCTION}

The drop in stock prices on the mining industry related to the value of the price book value (PBV), best downhill. PBV decline caused by the mining industry's share price dropped quite 
significantly. Decrease negative perceptions will create the PBV for investors against the company's performance that will have an impact on the decisions of investors, so companies should seek increase PBV. The decline in stock prices and a decline in revenues caused the PBV on the mining industry. Factors that also affect the performance of the mines was the decision of funding. The funding decision is the decision of financial management to get funds (either from the money market or capital market). After getting the funds, financial management of the acquired funds will invest into the company. Funding and investment decisions (either long term or short term) are of course interrelated. The investment amount determines the amount of funding that should be retrieved, and those investors who contributed to the Fund currently expects a return on investment in the future. Therefore, investments made companies currently have to produce returns in future to be paid to investors (Bidlle, 2006).

Investment can be defined as the expenditure or expenditure planter-capital investment or company to buy capital goods and supplies-production equipment to increase the capability of producing goods and services available in the economy (Sukirno 2013: 34). Investment is action to embed the funds owned at this time with the hope to gain an advantage in future (Darminto, 2010: 105). There are two types of investment decisions including investing assets of real and financial asset investments.

Rangkuti (2012) stated that investments are issued must produce an appropriate rate of return with the amount of capital issued, as well as the risks faced. Obstacles that may be encountered in building a project, namely the existence of changes in exchange rates, inflation rates, changes in purchasing power, a change in the condition of the economic macro. The greater the investment fund, then the greater the risk of loss is also encountered. By karna was the analysis of feasibility study needs to be done to minimize the risk of failure and loss. In terms of investment contained two important attributes, namely the existence of risks and time lag.

Funding decisions according to Kymee and Pudjiastuti (2006:251) funding Decisions regarding the shape and composition of the funding company that will be used. Murtini (2008) stated the funding Decision is the way how the company can fund the activities of its operation optimally, and also how the companies composing the optimal source of funding must be maintained. Husnan (2008:253-254) Funding Decisions regarding company decisions about the shape and composition of the funding that will be used by the company. In General, funds can be obtained from outside the company (external financing) as well as from within the company (internal financing). Decisions on external financing is often referred to as the funding decision, while internal financing concerning the dividend policy.

\section{LITERATURE REVIEW AND HYPOTHESIS}

\section{Risk of Strategic}

Dorfman (2004:8) risk management is a logical process used by the company's business and the individual. Strategic risk is the risk due to the lack of right bank in taking decisions and implementing strategic decisions or failure in anticipation of changes in the business environment. Strategic risks classified as business risk with different types of financial risk such as market risk, credit risk or The failure of the bank to manage strategic risks can impact significantly to changes in other risk profile. For example, the bank implemented a strategy of growth with the awarding of the high interest rates, a significant impact on liquidity risk profile changes or interest rate risk. Before discussing the problem of strategic risk, it's good we went back what is a management strategy, i.e. a series of decisions and action (action) will determine the performance of managerial and business continuity in Bank the long term. 


\section{Efficiency}

Mulyadi (2005:3) the efficiency is a measure of input usage plans in comparing with the use of a word or other use of the work of the actual Efficiency is something that we're working on with regard to produce optimal results by not throwing away a lot of time in the process of work effective is not necessarily efficient and so instead of efficiency is a measure of the success of the assessed in terms of the magnitude of the resource/cost to achieve results from the activity that is executed. Hasibuan (2001: 233-4) efficiency is the best comparison between input and output (result between the advantages with the sources used), as well as the optimal results are achieved with the use of a limited resource. Some things that can be done by the company to carry out the cost-efficiency is as follows: do the cost-efficiency of production, improve the efficiency and performance of employees and charge standard.

\section{Good Corporate Governance}

Zarkasyi (2008:36), GCG is primarily a system (input, process, output) and a set of rules governing the relationship between the various interested parties (stakeholders) especially in the narrow sense of the relationships between the shareholders, the Board of Commissioner, and the Board of Directors for the sake of goals. GCG set up relationships, prevent the occurrence of significant mistakes in the strategy of the company and to ensure that the mistakes that occurred can be corrected immediately. GCG has five main goals: protecting the rights and interests of shareholders, protecting the rights and interests of the members of the stakeholders to non shareholders, increasing the value of the company and shareholders, increasing the efficiency and effectiveness of work of the Board or the Board of Directors and management of the company and improve the quality of the relationship the Board of Directors with senior management of the company.

\section{Financial Performance}

Sucipto (2003:6) financial performance is the determination of specific measurements that can measure the success of an organization or company in generating profits. Poureisa, Ahmadgourabi, and Efteghar (2013) in Gamal and Soemantri (2017) Balanced performance card represents a system for measuring performance based on evaluating the organization development and growth, and enhancing its abilities with the goal to improve the customers satisfaction and the organizational effectiveness and efficacy. Performance measurement that is the qualifications and efficiency as well as effectiveness of the business operation of the company during the accounting period. the performance is a formal effort to evaluate the company implemented efficiently and the effectiveness of the company's activity has been implemented in a specific time period (Hanafi, 2007:69). To find out the financial performance of the company then in general need to do an analysis of the financial statements, which according to the Brigham and Houston (2007:78) includes (1) benchmarking the performance of the company with other companies in the same industry and (2) evaluation of the financial position of the company's trend over time.

\section{Value of Firm}

Andri and Hanung (2007) in Febrina (2010:5) the value of firm is to sell the company or growing value for our shareholders, the value of firm will be reflected in the market price of its shares. The increased value of the company is an achievement, which in accordance with the wishes of the owners, because with the increased value of the company, then the welfare of the owners also will increase, and it is the duty of the Manager as an agent that has been given by the owners of the company to run its business (Riyanto, 2010). 
The value of the company is very important because with the high value of the company will be followed by high prosperity of shareholders (Brigham and Gapenski, 1996). The wealth of the shareholders and the company presented by the market price of a stock is a reflection of the investment decision, funding (financing), and asset management.The value of the company in this study using measurement of the Price book value describes how big companies. The company goes well, generally have a price book value ratio above one, reflecting that the market value of the stock is greater than the value of the book. Price book value reflects a high level of prosperity, where shareholders prosperity for shareholders is the main purpose of the company (Weston and Brigham, 2000).

\section{Hypothesis}

1. Investment decisions effect significantly to efficiency in the mining company coal sector sub go public in Indonesia stock exchange.

2. Investment decision effect significantly to financial performance in the mining company coal sector sub go public in Indonesia stock exchange.

3. Investment decision effect significantly to value of firm on in the mining company coal sector sub go public in Indonesia stock exchange.

4. Funding decision effect significantly to efficiency in the mining company coal sector sub go public in Indonesia stock exchange.

5. Funding decision effect significantly to financial performance in the mining company coal sector sub go public in Indonesia stock exchange.

6. Funding decisions effect significantly to value of firm in the mining company coal sector sub go public in Indonesia stock exchange.

7. Risk of strategy effect significantly to efficiency of the mining company coal sector sub go public in Indonesia stock exchange.

8. Risk of strategy effect significantly to financial performance in the mining company coal sector sub go public in Indonesia stock exchange.

9. Risk of strategy effect significantly to value of firm in the mining company coal sector sub go public in Indonesia stock exchange.

10. Efficient effect significantly to efficiency on the financial performance of the mining company coal sector sub go public in Indonesia stock exchange.

11. Efficient effect significantly to the value of firm in the mining company coal sector sub go public in Indonesia stock exchange.

12. GCG as variables moderating effect significantly to value of firm in the mining company coal sector sub go public in Indonesia stock exchange.

13. GCG as variables moderating effect significantly to financial performance in the mining company coal sector sub go public in Indonesia stock exchange.

14. Financial performance effect significantly to value of firm in the mining company coal sector sub go public in Indonesia stock exchange. 


\section{CONCEPTUAL FRAMEWORK}

H 3

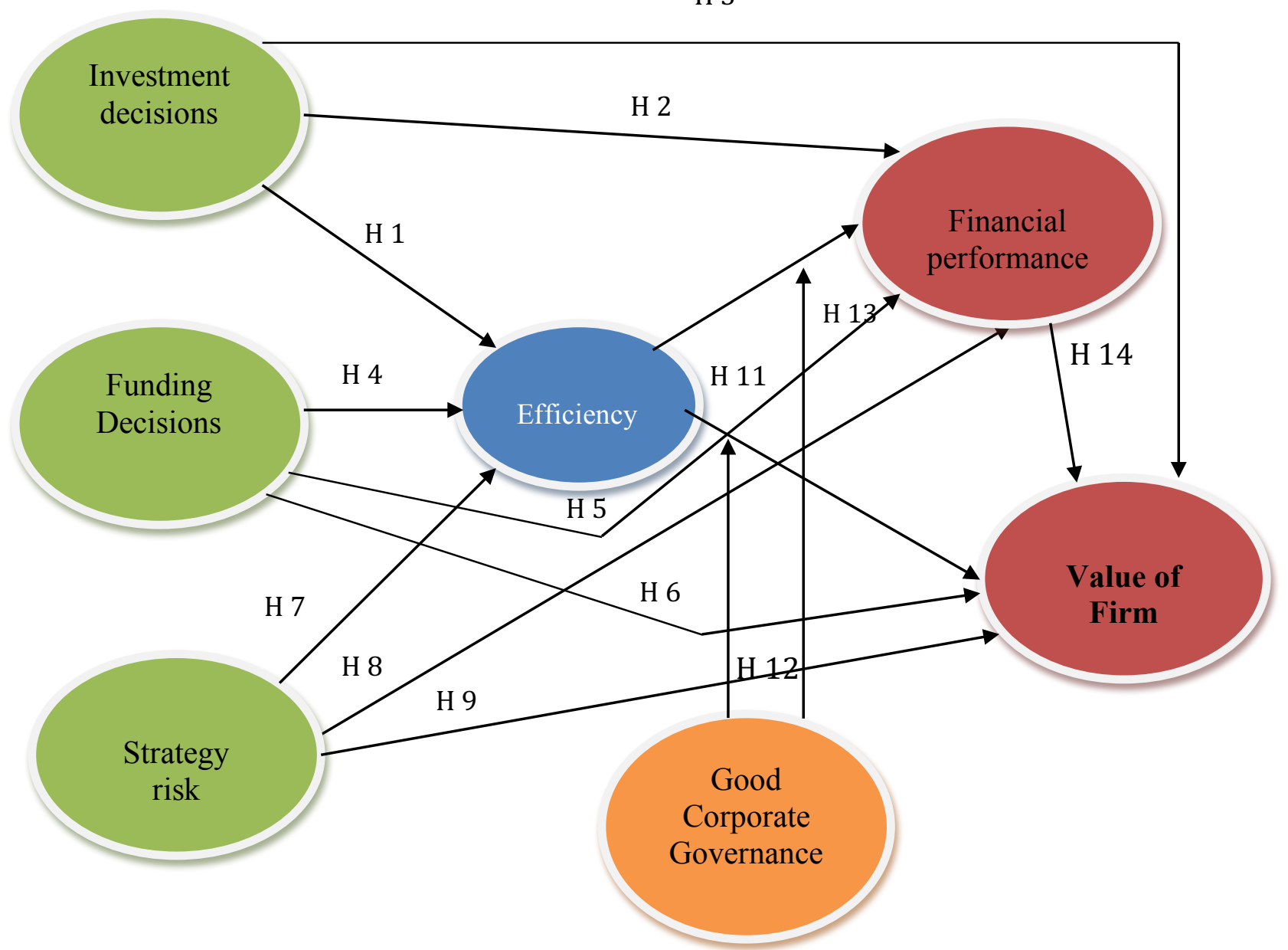

Figure 1 Conceptual Framework

\section{RESEARCH METHODS}

The object of the research is all of companies in the mining company coal sector sub go public on Indonesia stock exchange during the period of 2012 - 2016. Total sample is 18 companies which selected by purposive sampling. The sample selection method used is a purposive sample of nonprobabilitas i.e. with a view to obtaining a representative sample in accordance with the specified criteria, the criteria used for these samples as follows: The whole mining company coal sector sub go public on the Indonesia stock exchange (idx), The company has to publish annual financial reports consistently year 20012-2016 and the company's financial reports do not show the balance of profits and a negative equity in 2012-2016.

\section{ANALYSIS AND DISCUSSION}

To prove the hypothesis in this study that is looking at the significance of the influence between variable parameters and values of the coefficient on the significance ( $t$ statistic). On the things done PLS 2.0 by looking at Algorithm Boostrapping report, here's the result: 


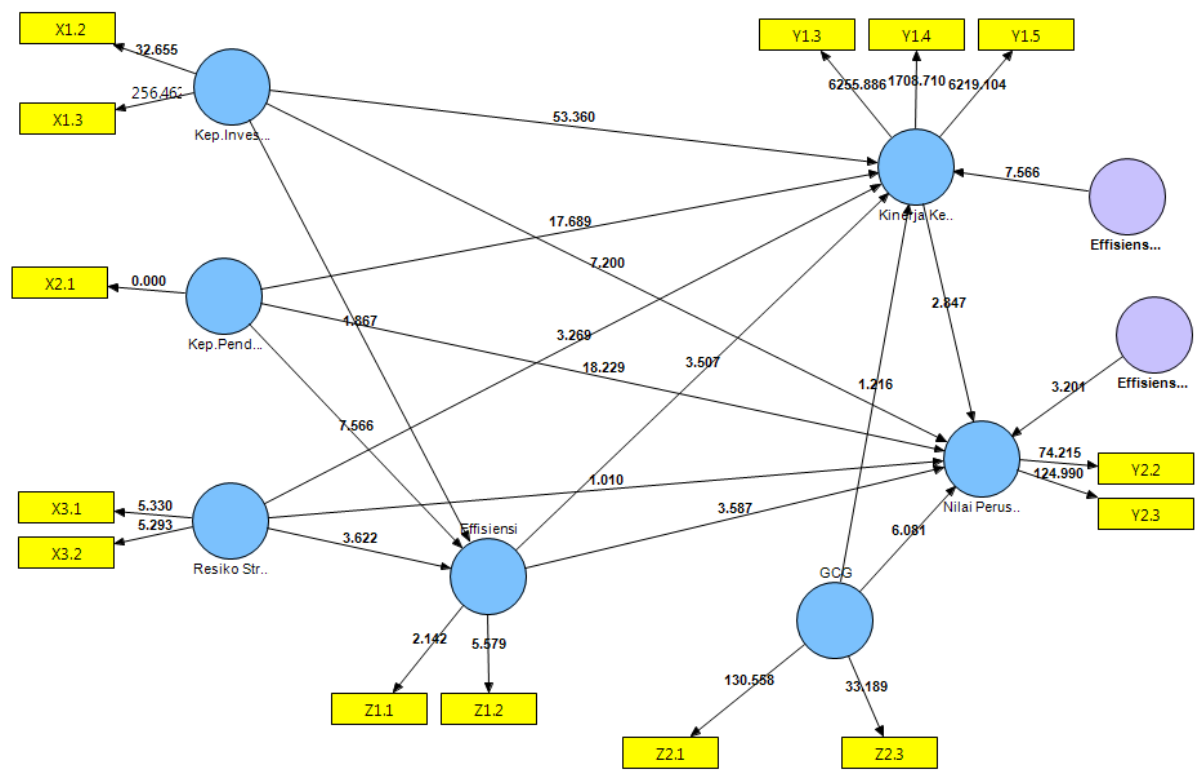

Figure 2. Output Bootstrapping

Table 2. Path Coefficients (Mean, STDEV, T-Values):

\begin{tabular}{|c|c|c|c|c|c|}
\hline & $\begin{array}{c}\text { Original } \\
\text { Sample }(0)\end{array}$ & $\begin{array}{l}\text { Sample } \\
\text { Mean (M) }\end{array}$ & $\begin{array}{l}\text { Standard } \\
\text { Deviation } \\
\text { (STDEV) }\end{array}$ & \begin{tabular}{|} 
Standard Error \\
(STERR)
\end{tabular} & $\begin{array}{l}\text { t Statistics } \\
(\mid 0 / \text { STERR } \mid)\end{array}$ \\
\hline $\begin{array}{l}\text { Investment decisions -> } \\
\text { efficiency }\end{array}$ & 0.038679 & 0.035718 & 0.020713 & 0.020713 & 1.867385 \\
\hline $\begin{array}{l}\text { Investment decisions -> value } \\
\text { of firm }\end{array}$ & 0.823310 & 0.822587 & 0.015429 & 0.015429 & 53.360209 \\
\hline $\begin{array}{l}\text { Investment decisions -> value } \\
\text { of firm }\end{array}$ & 0.247500 & 0.256004 & 0.034373 & 0.034373 & 7.200351 \\
\hline Funding decision -> efficiency & -0.160965 & -0.157652 & 0.021276 & 0.021276 & 7.565679 \\
\hline $\begin{array}{l}\text { Funding decision }->\text { financial } \\
\text { performance }\end{array}$ & 0.181853 & 0.180411 & 0.010281 & 0.010281 & 17.688573 \\
\hline $\begin{array}{l}\text { Funding decision -> value of } \\
\text { firm }\end{array}$ & -0.444117 & -0.432409 & 0.024364 & 0.024364 & 18.228646 \\
\hline Strategy risk -> efficiency & -0.077940 & -0.071950 & 0.021521 & 0.021521 & 3.621593 \\
\hline $\begin{array}{l}\text { Strategy risk -> financial } \\
\text { performance }\end{array}$ & 0.052181 & 0.046642 & 0.015963 & 0.015963 & 3.268839 \\
\hline Strategy risk -> value of firm & -0.047952 & -0.036374 & 0.047498 & 0.047498 & 1.009566 \\
\hline $\begin{array}{l}\text { efficiency -> financial } \\
\text { performance }\end{array}$ & 0.053622 & 0.049148 & 0.015288 & 0.015288 & 3.507431 \\
\hline efficiency -> value of firm & 0.470900 & 0.364499 & 0.131290 & 0.131290 & 3.586732 \\
\hline $\begin{array}{l}\text { financial performance -> value } \\
\text { of firm }\end{array}$ & -0.079712 & -0.090447 & 0.028000 & 0.028000 & 2.846819 \\
\hline $\begin{array}{l}\text { efficiency } * \text { GCG -> financial } \\
\text { performance }\end{array}$ & 0.097846 & 0.093651 & 0.012933 & 0.012933 & 7.565537 \\
\hline $\begin{array}{l}\text { efficiency * GCG -> value of } \\
\text { firm }\end{array}$ & -0.518745 & -0.396832 & 0.162058 & 0.162058 & 3.200984 \\
\hline
\end{tabular}

\section{Hypothesis Testing}

Path's shows the significance of the relationships between variables in the study. Thus giving 
the following result:

1. Investment decisions effect is not significantly to efficiency in mining sub sector of coal go public in Indonesia stock exchange relationship of investment decisions toward efficiency is effect not significant with t-statistic of $1.867385<1.96$ sample estimate of 0.038679 which indicates that the direction of the relationship between investment decisions against efficiency is unidirectional. Based on the results of sports data using 2.0 PLS give answers that hypothesis $1\left(\mathrm{H}_{1}\right)$ rejected.

2. Investment decision significant effect against the financial performance at the company's mining company coal sector sub go public in Indonesia stock exchange relationship of investment decisions toward financial performance is a significant effect with t-statistic of 53.360209 > original sample value of 1.96 estimate amounting to 0.823310 which suggests that the direction of the relationship between investment decisions toward financial performance is unidirectional. Based on the results of sports data using 2.0 PLS give answers that hypothesis $2\left(\mathrm{H}_{2}\right)$ accepted.

3. Investment decision significant effect against the value of firm on mining company coal sector sub go public in Indonesia stock exchange relationship of investment decisions of companies is significant with t-statistic of $7.200351>$ original sample value of 1.96 estimate amounting to 0.247500 which suggests that the direction of the relationship between the investment decisions of companies is unidirectional. Based on the results of sports data using 2.0 PLS give answers that hypothesis $3\left(\mathrm{H}_{3}\right)$ accepted.

4. Funding decisions against efficiency relationship is significant effect with t-statistic of $7.565679>1.96$ to the value of the original sample estimate of 0.160965 which indicates that the direction of the relationship between funding decisions against efficiency is the opposite. Based on the results of sports data using 2.0 PLS give answers that hypothesis $4\left(\mathrm{H}_{4}\right)$ accepted.

5. Funding decision significant effect to financial performance at the company's mining sub sector of coal go public in Indonesia stock exchange Relations funding decisions against the financial performance is a significant effect with t-statistic of $17.688573>$ original sample value of 1.96 estimate amounting to 0.181853 which suggests that the direction of the relationship between a funding decision against the financial performance is a direct. Based on the results of sports data using 2.0 PLS give answer to that hypothetical $5\left(\mathrm{H}_{5}\right)$ accepted.

6. Funding decision effect significantly to value of firm on mining company coal sector sub go public in Indonesia stock exchange Relations funding decisions against the value of the company is a significant effect with t-statistic of $18.228646>1.96$ to the value of the original sample estimate of 0.444117 which indicates that the direction of the relationship between the funding decisions of the company are in opposite directions. Based on the results of sports data using 2.0 PLS give answers that hypothesis $6\left(\mathrm{H}_{6}\right)$ accepted.

7. Strategy risk effect significantly to efficiency in mining sub sector of coal go public in Indonesia stock exchange Relationships risk strategy against efficiency was significantly influential with t-statistic of $3.621593>1.96$ to the value of the original sample estimate of 0.077940 which indicates that the direction of the relationship between the risk strategy towards efficiency is the opposite. Based on the results of sports data using 2.0 PLS give answers that hypothesis $7\left(\mathrm{H}_{7}\right)$ accepted.

8. Strategy risk effect significantly to financial performance at the company's mining sub sector of coal go public in Indonesia stock exchange Relationships risk strategy against financial performance is a significant effect with t-statistics of $3.268839>1.96$ to the value of the original sample estimate of 0.052181 which indicates that the direction of 
the relationship between the risk of strategy against financial performance is unidirectional. Based on the results of sports data using 2.0 PLS give answers that hypothesis $8\left(\mathrm{H}_{8}\right)$ accepted.

9. Strategy risk effect insignificant against the value of the company on mining company coal sector sub go public in Indonesia stock exchange Relationships risk strategy of a company is the effect not significant with t-statistic of 1.009566 the original value of 1.96 < sample estimate of 0.047952 which indicates that the direction of the relationship between the risk strategy of the company is in the opposite direction. Based on the results of sports data using 2.0 PLS give answers that hypothesis $9\left(\mathrm{H}_{9}\right)$ rejected.

10. Efficient effect significantly to efficiency on the financial performance on a mining company coal sector sub go public in Indonesia stock exchange relationship of efficiency against the financial performance is a significant effect with t-statistic of $3.507431>$ original sample value of 1.96 estimate amounting to 0.053622 which suggests that the direction of the relationship between the efficiency against the financial performance is unidirectional. Based on the results of sports data using 2.0 PLS give answer to that hypothetical $10\left(\mathrm{H}_{10}\right)$ accepted.

11. Efficient effect significantly to the value of the company on mining company coal sector sub go public in Indonesia stock exchange Relationships efficiency against the value of the company is a significant effect with t-statistics of $3.586732>$ original sample value of 1.96 estimate amounting to 0.470900 which suggests that the direction of the relationship between the efficiency of a company is unidirectional. Based on the results of sports data using 2.0 PLS give answers that hypothesis $11\left(\mathrm{H}_{11}\right)$ accepted.

12. Financial performance effect significantly to the value of the company on mining company coal sector sub go public in Indonesia stock exchange relationship of the financial performance of companies is significant with t-statistic of $2.846819>1.96$ to the value of the original sample estimate of 0.079712 which indicates that the direction of the relationship between the financial performance of the company are in opposite directions. Based on the results of sports data using 2.0 PLS give answers that hypothesis $12\left(\mathrm{H}_{12}\right)$ accepted.

13. GCG as influential moderating significantly to efficiency is the relationship with financial performance at the company's mining sub sector of coal go public in the Indonesia stock exchange of GCG as moderating variable efficiency of the relationship with financial performance is a significant effect with t-statistic of $7.565537>$ original sample value of 1.96 estimate amounting to 0.097846 which suggests that the direction of the influence GCG as the pemoderasi of the relationship with financial performance efficiency is unidirectional. Based on the results of sports data using 2.0 PLS give answers that hypothesis $13\left(\mathrm{H}_{13}\right)$ accepted.

14.GCG as influential moderating significantly to efficiency is the relationship with the value of the company on mining company coal sector sub go public in Indonesia stock exchange of GCG as moderating variable efficiency of the relationship with the value of the company is a significant effect with t-statistic of $3.200984>1.96$ to the value of the original sample estimate of 0.518745 which indicates that the direction of the influence of GCG as moderating variable of the relationship of the company with the highest efficiency is in the opposite direction. Based on the results of sports data using 2.0 PLS give answers that hypothesis $14\left(\mathrm{H}_{14}\right)$ accepted.

\section{SUMMARY}

1. Investment decisions don't effect significantly to efficiency on the mining company coal sector sub go public in Indonesia stock exchange.

2. Investment decision effect significantly to financial performance on the mining 
company coal sector sub go public in Indonesia stock exchange.

3. Investment decision effect significantly to value of firm on the mining company coal sector sub go public in Indonesia stock exchange

4. Funding decision effect significantly to efficiency on the mining company coal sector sub go public in Indonesia stock exchange.

5. Funding decision effect significantly to financial performance on the mining company coal sector sub go public in Indonesia stock exchange.

6. Funding decisions effect significantly to value of firm on the mining company coal sector sub go public in Indonesia stock exchange.

7. Risk of strategy effect significantly to efficiency of mining company coal sector sub go public in Indonesia stock exchange.

8. Risk of strategy effect significantly to financial performance on the mining company coal sector sub go public in Indonesia stock exchange.

9. Risk of strategy don't effect significantly to value of firm of mining company coal sector sub go public in Indonesia stock exchange

10. Efficient effect significantly to financial performance on the mining company coal sector sub go public in Indonesia stock exchange.

11. Efficient effect significantly to the value of firm on the mining company coal sector sub go public in Indonesia stock exchange.

12. GCG as moderating variable effect significantly to value of firm on the mining company coal sector sub go public in Indonesia stock exchange.

13. GCG as moderating variable effect significantly to financial performance on the mining company coal sector sub go public in Indonesia stock exchange.

14. Financial performance effect significantly to value of firm on the mining company coal sector sub go public in Indonesia stock exchange.

\section{LIMITATIONS}

1. For Further Research. In this study focused only on the independent variables only. For further research can add more factors that may affect the good corporate governance.

2. for investors the most Variables affect the quality of this investment decision is the value of companies an investor can see the size of the company as a basis for consideration of an investment. On the large scale companies tend to be doing the implementation of investment policy this was done to address the problem of Agency and improve the company's performance.

3. For other studies in this research note investment decision is the most variable affect the value of the company, then for companies with large scale should further enhance the investment decision to so easily get external funding.

\section{BIBLIOGRAPHY}

Biddle, Gary and Hilary Gilles. 2006. Accounting Quality and Firm- Level Capital Investment. Forthcoming, The Accounting Review.

Brigham, E. F., and J. F. Houston. 2001. Financial Management. Edition In Indonesian Language. Jakarta: Eason.

Darminto. 2010. The Influence of External Factors and The Various Financial Decisions Against The Value of The Company. Journal Management Application. Vol. 8. (1) February 2010. Things 138-150

Dorfman, Mark S. 2004, Inroduction to Risk Management and Insurance, Prentice Hall International, London.

Gamal, A. and Soemantri, A.I., 2017. The Effect of Balanced Scorecard on the Private College Performance (Case Study at the University of WR Supratman Surabaya). Archives of Business Research, 5(5), 126-134.

Hanafi, Mahmoud M. 2012. The Basics of Financial Management. The Publisher Of The Balai Pustaka. Jakarta. 
Hasibuan, Melayu S.P. 2009. Management: Basics, Understanding, and Issue revised edition. Jakarta: The Earth Revised

Husnan, Suad. 2008. Financial Management: Theory and Implementation. Book 1. Edisi4. BPFE. Yogyakarta.

Mulyadi. 2007. Management Accounting: concepts, benefits, and engineering, 3rd Edition, Jakarta: Salemba Empat. Rangkuti, Freddy. 2012. Business Investment feasibility study. Main Library Gramedia. Jakarta.

Riyanto, Bambang. 2008. Foundations of Corporate Spending. Yogyakarta: Publisher GPFE.

Zarkasyi, Wahyudin. 2008. Good Corporate Governance On Business Entities Manufacturing, Banking and Other Financial Services. Bandung: Alfabeta 